\author{
Wiestawa Gierańczyk, Agata Sadoch \\ Urząd Statystyczny w Bydgoszczy, Toruń, Polska • Statistical Office in Bydgoszcz, Toruń, Poland
}

\title{
Współdziałanie aktywnych innowacyjnie przedsiębiorstw przemysłowych w Polsce według województw w latach 2010-2012
}

\section{Cooperation of innovate industrial enterprises in Poland by voivodeships (2010-2012)}

\begin{abstract}
Streszczenie: Innowacje kojarzone są z postępem i nowoczesnością, a ich dyfuzja do sfery praktycznego funkcjonowania przyczynia się w dużej mierze do rozwoju gospodarczego. Stanowią one siłę napędową gospodarki, są bowiem specyficznymi narzędziami przedsiębiorczości. Ta zaś, wyrażająca się w ciągłym poszukiwaniu nowych koncepcji czynników wytwórczych, jest motorem postępu gospodarczego. Zasadniczym celem wprowadzania innowacji w przedsiębiorstwach jest dążenie do osiągnięcia przewagi konkurencyjnej. Globalny i mocno konkurencyjny rynek powoduje jednak, że bycie innowacyjnym nie przesądza o sukcesie. Na przedsiębiorstwach zaangażowanych w proces tworzenia innowacji wymusza on poszukiwanie coraz to nowych rozwiązań. Zarówno w literaturze naukowej, jak i w dokumentach strategicznych wskazuje się, że rozwiązaniem pozytywnie wpływającym na wzrost gospodarczy i rozwój regionów jest współpraca wszystkich aktorów procesu innowacyjnego. W Polsce jedną z najbardziej widocznych słabości systemu innowacji jest brak współpracy i powiązań między podmiotami. Stąd w niniejszym artykule dokonano diagnozy sytuacji w zakresie poziomu współpracy oraz form współdziałania przedsiębiorstw na przykładzie aktywnych innowacyjnie przedsiębiorstw przemysłowych w latach 2010-2012 wg województw. Podstawę do części analitycznej niniejszego artykułu stanowiły wyniki badania o innowacjach w przemyśle przeprowadzonego w 2013 roku przez Główny Urząd Statystyczny (GUS). Przewidziany w badaniu poziom agregacji danych zdeterminował przestrzenny aspekt analiz na poziomie województw.
\end{abstract}

Abstract: Innovations are usually associated with the progress and modernity, and when they spread to the sphere of the functioning, they highly contribute to the economic development. They are impulsion of the economic growth because of their role of a specific entrepreneurship tool. The entrepreneurship, meant as a continuous search of the new creative factors conceptions, is the engine of the economic development. However, being innovative does not determine the success. The actors involved in the process of innovation must seek ever new solutions. This solution must be sold or implemented successfully. New products have to hit the markets with ever increasing speed. By the scientific literature and policy documents, development cooperation between actors is one of key features for achieving economic development results. But in Poland one of the most pronounced weaknesses of the Polish innovation system is the lack of cooperation and linkages between different actors. In this paper we have also diagnosed the situation in terms of the level of cooperation and kinds of cooperation between 
actors in the voivodeships in Poland. From that point of view, we have analyzed the activity of the innovated industrial companies in 2010-2012. The basis of this analyses were the results of the survey of the innovation in the industry. This survey was carried out by the Central Statistical Office of Poland in 2013 .

Słowa kluczowe: inicjatywa klastrowa; innowacja; przedsiębiorstwo aktywne innowacyjnie; współpraca w działalności innowacyjnej

Keywords: cluster initiative; innovation, innovation active enterprise; innovation co-operation

Otrzymano: 18 grudnia 2014

Received: 18 December 2014

Zaakceptowano: 31 lipca 2015

Accepted: 31 July 2015

\section{Sugerowana cytacja / Suggested citation:}

Gierańczyk, W., Sadoch, A. (2015). Współdziałanie aktywnych innowacyjnie przedsiębiorstw przemysłowych w Polsce według województw w latach 2010-2012. Prace Komisji Geografii Przemystu Polskiego Towarzystwa Geograficznego, 29(4), 68-84.

\section{WSTĘP}

W polskiej gospodarce dokonują się przemiany ilościowe i jakościowe, zbliżające ją do struktur charakterystycznych dla krajów z rozwiniętą gospodarką rynkową. Zmienne i silnie konkurencyjne otoczenie wymusza na współczesnych przedsiębiorstwach poszukiwanie nowych rozwiązań, ponieważ borykają się one z coraz trudniejszymi i bardziej skomplikowanymi warunkami rozwoju. Należą do nich m.in. większa agresywność przedsiębiorstwa i zwiększenie jego tzw. turbulencji (więcej nowości, szybkie zmiany, złożone i intensywne otoczenie), niespotykana dotąd dynamika procesów globalizacyjnych, nowe wymogi konkurencyjne i natężenie konkurencji oraz błyskawiczny postęp technologiczny. Wszystko to sprawia, że umiejętności dążenia do stałego rozwoju przedsiębiorstwa, czyli ciągła analiza sygnałów płynących z otoczenia, podejmowanie trafnych decyzji strategicznych i wprowadzanie odpowiednich zmian w organizacji, nabierają szczególnego znaczenia (Toborek-Mazur, 2004:198). Proces ten ma charakter dynamiczny, a jego celem jest zwiększenie konkurencyjności przedsiębiorstw i całej gospodarki na międzynarodowym rynku.

Abstrahując od trudności w rozumieniu, definiowaniu i interpretacji, konkurencyjność przedsiębiorstw $^{1}$ zawsze była istotnym warunkiem ich powodzenia, a w dobie globalizacji stała się wyznacznikiem istnienia. Jak wskazuje R. Tylżanowski (2012: 393-406), konkurencyjność na rynku jest efektem oddziaływania wielu mechanizmów i czynników, zarówno wewnętrznych, dotyczących przedsiębiorstwa, jak i zewnętrznych, istniejących w otoczeniu. Wśród przesłanek wewnętrznych za istotne uznaje się obecnie innowacyjność i zdolność do wprowadzania postępu technologicznego w firmach (Mazur-Wierzbicka, 2007: 31).

Jedną z najbardziej widocznych słabości systemu innowacji w Polsce jest brak współpracy i powiązań między podmiotami. Stąd celem niniejszego artykułu jest diagnoza (2008).

${ }^{1}$ Szerzej teoretyczne kwestie konkurencyjności przedsiębiorstw rozważali m.in. M. Gorynia i B. Jankowska 
współpracy aktywnych innowacyjnie przedsiębiorstw przemysłowych w latach 2010-2012 oraz wskazanie województw podobnych do siebie pod względem realizowanych w tym czasie form kooperacji. Podstawę do części analitycznej artykułu stanowiły wyniki badania o innowacjach w przemyśle, przeprowadzonego w 2013 roku przez GUS. Badanie to było częścią międzynarodowego programu badawczego Community Innovation Survey i objęło pełną zbiorowość przedsiębiorstw przemysłowych ${ }^{2}$, w których pracowało co najmniej 50 osób, oraz próbę jednostek, w których pracowało od 10 do 49 osób. Badanie odnosiło się do działań innowacyjnych w latach 2010-2012. Ze względu na założenia badania zakres przestrzenny niniejszej analizy ograniczono do poziomu województw - najniższego poziomu dostępności przedmiotowych danych.

\section{AKTYWNOŚĆ INNOWACYJNA PRZEDSIĘBIORSTW PRZEMYSŁOWYCH}

Poziom aktywności innowacyjnej polskich przedsiębiorstw przemysłowych w latach 2010-2012 w Polsce (firmy aktywne innowacyjnie na ogół zakładów przemysłowych) wyniósł średnio $17,7 \%{ }^{3}$ i był zróżnicowany przestrzennie. Współczynnik zmienności $\left(\mathrm{V}_{\mathrm{s}}\right)$ aktywności innowacyjnej przedsiębiorstw przemysłowych wg województw wyniósł 18\%, przy czym wskaźnik tej aktywności kształtował się od 23,8\% w województwie podlaskim, do $12,3 \% \mathrm{w}$ pomorskim.

To zróżnicowanie wskazuje, że w wojewódzkich układach regionalnych przedsiębiorstwa przemysłowe wykazują różną wewnętrzną zdolność do:

a) tworzenia nowych produktów, technologii lub metod organizacji oraz absorpcji i

b) zastosowania wiedzy wytworzonej poza przedsiębiorstwami.

Zauważa się przy tym, że we wszystkich województwach aktywność innowacyjna rosła wraz z wielkością przedsiębiorstw ${ }^{4}$ (ryc. 2), ale poziom jej zróżnicowania w poszczególnych województwach był odmienny. W analizowanym okresie najmniejsza zmienność udziału aktywnych innowacyjnie przedsiębiorstw występowała w grupie dużych zakładów $\left(\mathrm{V}_{\mathrm{s}}=11,2 \%\right)$. Udział ten wahał się od $65,1 \% \mathrm{w}$ województwie małopolskim do 43,9\% w zachodniopomorskim.

Poziom aktywności innowacyjnej obniżał się wraz z coraz mniejszym rozmiarem przedsiębiorstw. Aktywnych innowacyjnie firm wśród średnich zakładów przemysłowych było w analizowanym okresie przeciętnie 31,6\%, przy czym największy ich udział (37\%) odnotowano w województwie opolskim, a najmniejszy $(23,1 \%)$ - w pomorskim. Należy przy tym zauważyć, że zmienność rozkładu aktywności innowacyjnej tej grupy w województwach była podobna jak w dużych przedsiębiorstwach. $\mathrm{V}_{\mathrm{s}}$ kształtował się na poziomie 12,3\%.

${ }^{2}$ Czyli prowadzących działalność gospodarczą zaklasyfikowaną według PKD do sekcji: B, C, D i E.

${ }^{3}$ Według badania GUS pt. Sprawozdanie o innowacjach $w$ przemyśle $w$ latach 2010-2012. Metodologia badania działalności innowacyjnej przedsiębiorstw przyjęta przez GUS jest zgodna z międzynarodowymi zaleceniami metodologicznymi opracowanymi przez OECD oraz Eurostat i zamieszczonymi w serii podręczników Frascati Family Manuals.

${ }^{4}$ Czyli przedsiębiorstwa, w których pracuje od 10 do 49 osób (małe), od 50 do 249 osób (średnie) i powyżej 249 osób (duże). 
Z kolei w małych zakładach przemysłowych poziom aktywności innowacyjnej był trzykrotnie niższy niż w średnich i niemal sześciokrotnie niższy niż w dużych. Udział podmiotów aktywnych innowacyjnie w grupie małych przedsiębiorstw wahał się od 19,5\% w województwie podlaskim do 4,1\% w wielkopolskim. Jednocześnie zmienność rozkładu tego wskaźnika w województwach była najwyższa $\left(\mathrm{V}_{\mathrm{s}}=32,6 \%\right)$ wśród analizowanych grup przedsiębiorstw (czyli małych, średnich i dużych).

Ryc. 1. Skupienia województw podobnych pod względem udziału przedsiębiorstw przemysłowych aktywnych innowacyjnie w latach 2010-2012 w ogólnej liczbie przedsiębiorstw przemysłowych

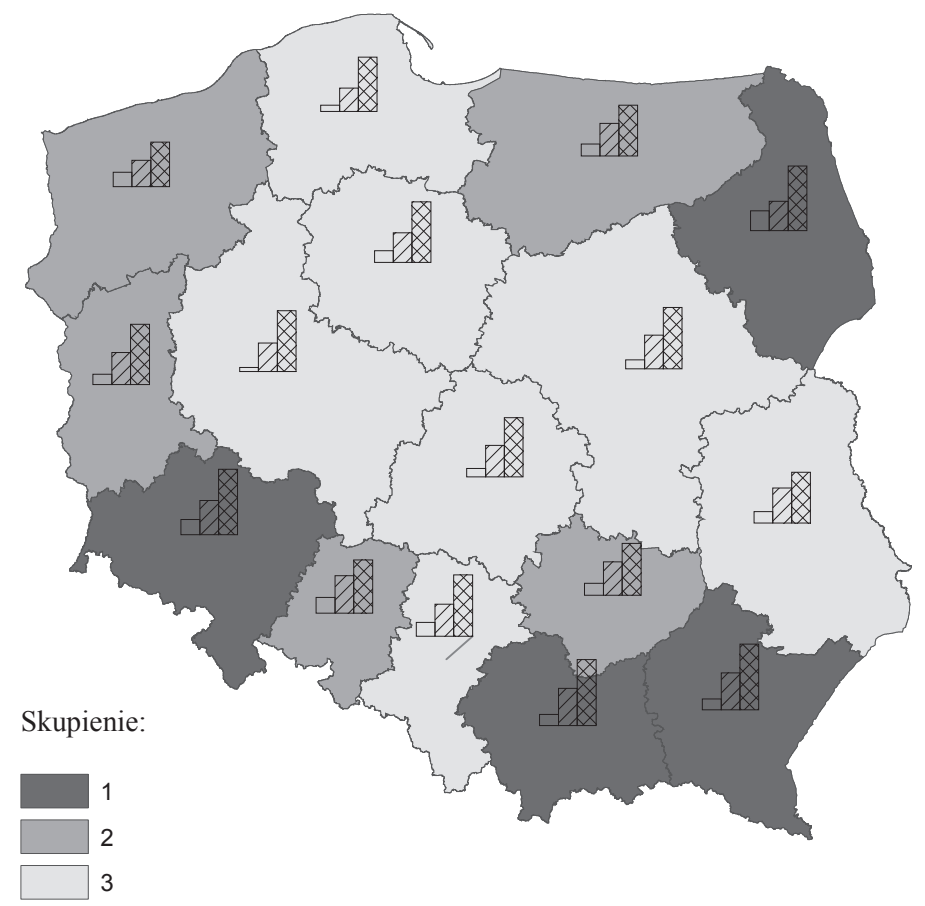

Udział aktywnych innowacyjnie przedsiębiorstw przemysłowych w ogólnej liczbie przedsiębiostw przemysłowych wg wielkości (\%):

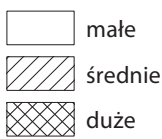

Źródło: opracowanie własne na podstawie danych GUS

Analiza podobieństwa województw (przeprowadzona metodą Warda przy wykorzystaniu odległości euklidesowej) pod względem udziału podmiotów przemysłowych aktywnych innowacyjnie w latach 2010-2012 w ogólnej liczbie przedsiębiorstw przemysłowych w analizowanych grupach wielkości, wykazała bliskość geograficzną województw w Polsce 
centralnej (skupienie trzecie). Skupienie to cechował, niezależnie od wielkości firm, niższy niż średni w Polsce udział przedsiębiorstw aktywnych innowacyjnie, przy czym aktywność małych zakładów była tu najniższa spośród wydzielonych skupień. Natomiast aktywność innowacyjna małych podmiotów była domeną przedsiębiorstw w województwach zakwalifikowanych do skupień pierwszego i drugiego. Należy zauważyć, że w skupieniu pierwszym aktywność innowacyjna ogółem była wyższa niż średnia w Polsce. Skupienie drugie, oprócz wspomnianej aktywności małych podmiotów, cechowała zbliżona do poziomu krajowego aktywność przedsiębiorstw średniej wielkości oraz najniższa spośród analizowanych grup aktywność dużych zakładów (o blisko 8 p.p. wyższa niż w tej grupie wielkości przedsiębiorstw w Polsce).

Jak wynika z powyższego opisu, w latach 2010-2012 w Polsce większe trudności z podejmowaniem aktywności innowacyjnej miały małe i średnie przedsiębiorstwa (MSP). Wniosek ten jest zgodny z wynikami wielu badań (m.in. Wolak, Żmijewska, 2014; Stawasz, 2011; Klonowski, 2009; Dominiak, Wasilczuk, Daszkiewicz, 2005), które mówią, że małe i średnie firmy mają większe problemy niż duże podmioty gospodarcze, zwłaszcza w wyszukiwaniu i ocenianiu różnorodnych zasobów zewnętrznych, ich asymilacji, transformacji i zastosowaniu. Mniejsze przedsiębiorstwa są też bardziej wrażliwe na jakość i otwartość otoczenia. Wynika to m.in. z faktu, że MSP w większym stopniu opierają się na nieformalnych, a więc trudno mierzalnych działaniach badawczo-rozwojowych $(\mathrm{B}+\mathrm{R})$ i rzadziej korzystają z zewnętrznych źródeł wiedzy (usług doradczych oraz licencji) niż ich większe odpowiedniki. Odzwierciedla to mniejszą zdolność małych i średnich firm do absorpcji wiedzy zewnętrznej (Ortt, van der Duin, 2008). P. Larsen i A. Lewis (2007) do głównych czynników ograniczających innowacyjność MSP zaliczyli: ograniczenia finansowe i czasowe, niedostatek umiejętności marketingowych, nieprawidłowości w zarządzaniu i utrudniony dostęp do zewnętrznych usług konsultingowych.

Opisane powyżej zjawiska są szczególnie niekorzystne w dobie globalnej gospodarki, przejawiającej się tym, że działania podejmowane przez podmioty gospodarcze zachodzą w czasie rzeczywistym na skalę całej planety i nie tylko wzmagają walkę konkurencyjną, ale znacznie zwiększają liczbę uczestników tej walki. Oznacza to, że obecnie bycie innowacyjnym nie przesądza o sukcesie. Jako jedną z metod rozwiązania tych trudności, będących konsekwencją zachodzących procesów (zwłaszcza, choć nie tylko, dla sektora MSP), wskazuje się drogę współpracy z innymi uczestnikami rynku. Zwłaszcza współpraca firm zajmujących się działalnością innowacyjną jest bardzo pożądana we współczesnej gospodarce. M. Rosińska (2007) wymienia właśnie współpracę podmiotów gospodarczych jako jedną z podstawowych przesłanek stabilnego, długookresowego rozwoju przedsiębiorstw w dobie globalizacji. Rozwój wszelkiego typu formalnych i nieformalnych powiązań, opartych na kompetencjach i wzajemnym zaufaniu, może bowiem przynieść wiele korzyści, począwszy od szerszego dostępu do wiedzy i nowych technologii, po obniżenie kosztów i ryzyka prowadzonej działalności oraz zapewnienie stabilnego rozwoju na bazie innowacyjnych zmian jakościowych. Dzięki tym powiązaniom możliwe jest amortyzowanie skutków nagłych, krótkich kryzysów i utrzymanie w długim okresie wysokich wskaźników wzrostu, opierających się na wielopłaszczyznowej współpracy sieciowej. 
Należy jednak mieć świadomość, że współpraca przy innowacjach, oznaczająca aktywny udział we wspólnych projektach badawczo-rozwojowych i innych rodzajach działalności innowacyjnej (The measurement..., 1997), nie powinna być jednorazowym aktem, lecz perspektywicznym i długofalowym procesem. Zazwyczaj bowiem nie od razu ujawniają się bezpośrednie, wymierne korzyści ekonomiczne dla jej uczestników. Partnerami w działalności innowacyjnej, poza instytucjami $\mathrm{B}+\mathrm{R}$, generującymi wiedzę i innowacje, są przedsiębiorstwa i organizacje pośredniczące w transferze innowacji. Skala, zakres i efektywność współpracy są determinowane interakcjami zachodzącymi między nimi. Stąd osiągnięcie korzyści powinno być stymulowane przez tworzenie systemów innowacyjnych, rozumianych jako kompleksy instytucji i łączących je powiązań, dzięki którym dana gospodarka stanowi sprawny mechanizm tworzenia i dyfuzji wiedzy (Klastry, 2014).

Organizacja Współpracy Gospodarczej i Rozwoju (OECD) wyróżniła cztery formy powiązań w systemie innowacyjnym:

1) powiązania przedsiębiorstwo - przedsiębiorstwo, w tym powiązania z komercyjnymi, wiedzochłonnymi usługami dla biznesu (np. wspólna działalność B+R, wspólne produkty, patenty),

2) powiązania przedsiębiorstwo - sfera nauki i badań oraz publiczne instytucje transferu technologii (wspólna działalność B+R),

3) rynkowy transfer technologii, czyli dyfuzja wiedzy i innowacji drogą np. zakupu maszyn, urządzeń, licencji (wydatki pośrednie na B+R),

4) mobilność pracowników oraz transfer wiedzy ukrytej, nieutożsamionej.

Istotę tych powiązań stanowi rozwój rozumiany jako efektywne dostosowywanie się do zmiennego otoczenia. Nie ma przy tym granic tej współpracy ani w sensie przedmiotu działań, ani ich umiejscowienia w czasie i przestrzeni. Współpraca może mieć zatem charakter lokalny (w bezpośrednim otoczeniu przedsiębiorstwa) lub szerzej - międzynarodowy, obejmujący podmioty zagraniczne (Ratajczak-Mrozek, 2013).

Badania nad innowacyjnością przedsiębiorstw przeprowadzone $\mathrm{w}$ ramach Community Innovation Survey w państwach Unii Europejskiej dowiodły, że najwięcej interakcji i współpracy zachodzi między elementami systemu innowacyjnego na poziomie regionalnym. Jednocześnie większość regionów tworzy odrębną politykę i strategie proinnowacyjne, wpływając tym samym na zachowania innowacyjne firm i innych elementów systemu na swoim terenie (Burzyński, Kłosiewicz-Górecka, Kuczewska, Słonimska, 2008). Taką sytuację obserwuje się w Polsce, gdzie, jak wynika z analizy danych GUS, skala współpracy przedsiębiorstw przemysłowych zajmujących się działalnością innowacyjną jest zróżnicowana przestrzennie $\left(\mathrm{V}_{\mathrm{s}}=18,7 \%\right)$.

WSPÓŁPRACA AKTYWNYCH INNOWACYJNIE PRZEDSIĘBIORSTW PRZEMYSŁOWYCH PRZY DZIAŁALNOŚCI INNOWACYJNEJ

W latach 2010-2012 wśród aktywnych innowacyjnie podmiotów największy udział tych, które współpracowały z innymi podmiotami, zanotowano w województwach łódzkim 
i mazowieckim (odpowiednio 42\% i 41\%). Relatywnie najmniejsze zainteresowanie współpracą w działalności innowacyjnej zauważa się wśród aktywnych innowacyjnie podmiotów z województwa warmińsko-mazurskiego, gdzie niemal $80 \%$ z nich zadeklarowało, że nie podejmowało żadnych form tego rodzaju współpracy.

Podobnie jak poziom aktywności innowacyjnej polskich przedsiębiorstw przemysłowych, tak udział tych podmiotów, które współpracowały z innymi przy innowacjach, w ogólnej liczbie przebadanych, zarówno w Polsce, jak i w województwach, wzrastał wraz ze wzrostem wielkości podmiotów (ryc. 2). Podobne tendencje zaobserwowano też przy zmienności rozkładu przestrzennego zaangażowania zakładów przemysłowych we współpracę innowacyjną.

We wszystkich województwach najwięcej przedsiębiorstw współpracowało wśród dużych przedsiębiorstw aktywnych innowacyjnie. Wśród nich najaktywniejsze były te z województwa podkarpackiego (ponad 73\% ogółu aktywnych innowacyjnie podmiotów przemysłowych z tego terenu współpracowało z innymi jednostkami przy działalności innowacyjnej), a najmniej aktywne - z województwa warmińsko-mazurskiego (31\%). W tej grupie wielkości przedsiębiorstw $\mathrm{V}_{\mathrm{s}}$ udziału podmiotów współpracujących przy innowacjach $\mathrm{z}$ innymi w ogólnej liczbie aktywnych innowacyjnie zakładów przemysłowych wyniósł 17,4\%. Jednocześnie duże firmy przemysłowe były jedyną grupą, w której udział przedsiębiorstw współpracujących z innymi przedsiębiorstwami lub instytucjami był niższy niż udział podmiotów aktywnych innowacyjnie w latach 2010-2012 w ogólnej liczbie przedsiębiorstw przemysłowych (o 0,8 p.p.).

Skłonność do współpracy w ramach jakiejkolwiek inicjatywy wykazywała przeciętnie w Polsce ok. 1/3 średnich firm. W tej grupie najbardziej zaangażowane we współpracę były firmy w województwie podlaskim (46,7\%), a najmniej - w lubuskim (27,8\%). Rozkład był stosunkowo równomierny $-\mathrm{V}_{\mathrm{s}}$ udziału średnich przedsiębiorstw przemysłowych współpracujących przy działalności innowacyjnej z innymi podmiotami wyniósł 14,8\%.

W grupie małych firm przemysłowych aktywnych innowacyjnie najwięcej współpracowało firm z województw łódzkiego i mazowieckiego, o czym świadczy wysoka wartość wskaźnika ich udziału w ogólnej liczbie aktywnych innowacyjnie przedsiębiorstw tej wielkości - odpowiednio 39\% i 35\%. Największy problem ze współpracą miały natomiast małe firmy w województwach kujawsko-pomorskim, pomorskim i lubelskim - współpracowało tu mniej niż 10\% podmiotów. W tej grupie najgorzej wypadło województwo kujawsko-pomorskie, gdzie współpracowało zaledwie 4\% małych firm.

Z przeprowadzonych badań wynika, że pomiędzy ogólnym poziomem aktywności innowacyjnej a zaangażowaniem przedsiębiorstw przemysłowych we współpracę przy działalności innowacyjnej z innymi instytucjami lub firmami praktycznie nie zachodzi zależność korelacyjna $(\mathrm{r}=0,11)$. Liczba i rozkład skupień województw podobnych pod względem udziału przedsiębiorstw przemysłowych współpracujących przy działalności innowacyjnej z innymi instytucjami lub firmami w ogólnej liczbie przedsiębiorstw przemysłowych aktywnych innowacyjnie w latach 2010-2012 wskazują na różnorodne podejście podmiotów do współpracy (ryc. 2). 
Ryc. 2. Skupienia województw podobnych pod względem udziału przedsiębiorstw przemysłowych współpracujących z innymi przedsiębiorstwami lub instytucjami w ogólnej liczbie przedsiębiorstw przemysłowych aktywnych innowacyjnie

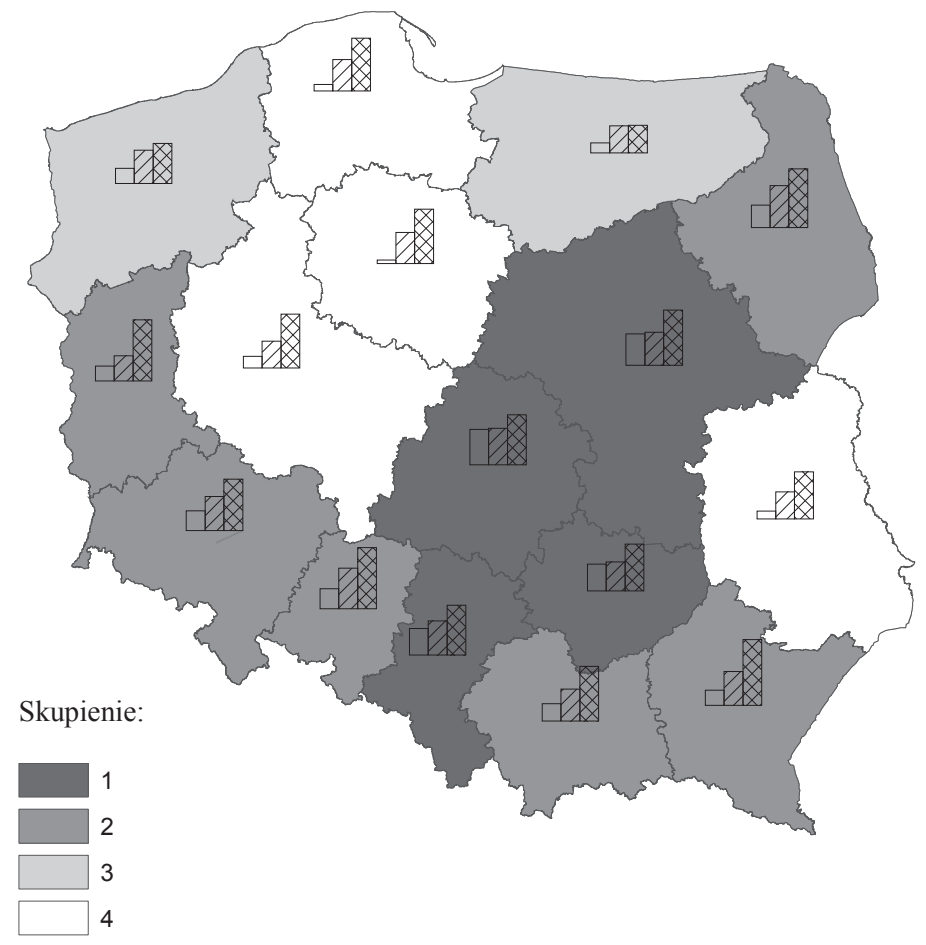

Udział aktywnych innowacyjnie przedsiębiorstw przemysłowych współpracujących w zakresie działalności innowacyjnej z innymi przedsiębiorstwami lub instytucjami w ogólnej liczbie przedsiębiorstw przemysłowych aktywnych innowacyjnie wg wielkości (\%):

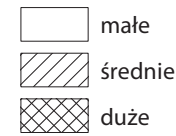

Źródło: opracowanie własne na podstawie danych GUS

Poziomem zaangażowania we współpracę najbardziej zbliżonym do średniej w Polsce odznaczało się skupienie drugie. Skupienie pierwsze wyróżniała natomiast bardzo duża skłonność do współpracy małych firm (o ok. 5 p.p. wyższa niż średnio w przedsiębiorstwach przemysłowych w Polsce) oraz zbliżona do przeciętnej w kraju aktywność tego rodzaju średnich i dużych podmiotów. Z kolei w skupieniach trzecim i czwartym znalazły się województwa, w których, niezależnie od wielkości firm, ich zaangażowanie we współpracę było zasadniczo niższe niż średnio w Polsce, przy czym najbardziej zbliżone wskaźniki występowały w grupie przedsiębiorstw średnich. Skupienie trzecie cechowała o 1/3 niższa niż średnio w kraju skłonność do współpracy małych i dużych firm. W skupieniu czwartym 
znalazły się województwa, w których zaangażowanie małych podmiotów było niewielkie. Średnio w tym skupieniu udział przedsiębiorstw przemysłowych współpracujących przy działalności innowacyjnej z innymi podmiotami w ogólnej liczbie aktywnych innowacyjnie w latach 2010-2012 był o 14 p.p. niższy niż średnio w Polsce, podczas gdy aktywność ta wśród przedsiębiorstw średnich i dużych pozostawała tylko na nieco niższym poziomie niż przeciętnie w kraju.

\section{WYBRANE FORMY WSPÓŁPRACY AKTYWNYCH INNOWACYJNIE PRZEDSIĘBIORSTW PRZEMYSLOWYCH}

Szczególną formą współpracy przy działalności innowacyjnej jest współpraca w ramach inicjatyw klastrowych. Rozwijanie i wspieranie właśnie tej formy kooperacji przedsiębiorstw jest obecnie uważane za najlepszy sposób na zwiększenie konkurencyjności gospodarki. Jest ona planowana i rozwijana m.in. w krajowych i wojewódzkich strategiach rozwoju. Należy jednak zwrócić uwagę, że w literaturze przedmiotu i dokumentach strategicznych ukierunkowujących rozwój jednostek przestrzennych istnieje wiele ujęć ,inicjatywy klastrowej”. Ponadto, jak wskazuje choćby A.M. Kowalski (2010), zdarza się niezasadne używanie pojęcia „,inicjatywa klastrowa” jako synonimu słowa „klaster”.

W polskiej literaturze przedmiotu zazwyczaj przyjmuje się za punkt wyjścia rozumienie klastra za M.E. Porterem (2001: 246), czyli jako ,geograficzne skupisko wzajemnie powiązanych firm, wyspecjalizowanych dostawców, jednostek świadczących usługi, firm działających w pokrewnych sektorach i związanych z nimi instytucji (na przykład uniwersytetów, jednostek normalizacyjnych i stowarzyszeń branżowych) w poszczególnych dziedzinach, konkurujących między sobą, ale również współpracujących. Klastry osiągające masę krytyczną (niezbędna liczba firm i innych instytucji tworząca efekt aglomeracji) i odnoszące niezwykłe sukcesy konkurencyjne w określonych dziedzinach działalności są uderzającą cechą niemal każdej gospodarki narodowej, regionalnej, stanowej, a nawet wielkomiejskiej, głównie w krajach gospodarczo rozwiniętych".

W rozporządzeniu Ministra Gospodarki z 2 grudnia 2006 roku w sprawie udzielania przez Polską Agencję Rozwoju Przedsiębiorczości pomocy finansowej niezwiązanej z programami operacyjnymi klaster został określony jako ,przestrzenna i sektorowa koncentracja podmiotów działających na rzecz rozwoju gospodarczego lub innowacyjności oraz co najmniej dziesięciu przedsiębiorców, wykonujących działalność gospodarczą na terenie jednego lub kilku sąsiednich województw, konkurujących i współpracujących w tych samych lub pokrewnych branżach oraz powiązanych rozbudowaną siecią relacji o formalnym i nieformalnym charakterze, przy czym co najmniej połowę podmiotów funkcjonujących w ramach klastra stanowią przedsiębiorcy" (Rozporządzenie..., 2014).

Pomimo różnic w rozumieniu pojęcia „klaster” utożsamianie go z inicjatywą klastrową wydaje się nawarstwiać i tak już występujące trudności rozumienia ,inicjatywy klastrowej”. Na przykład wg A.M. Kowalskiego (2010) inicjatywa klastrowa to mniej lub bardziej sformalizowana i zinstytucjonalizowana działalność grupy aktorów lokalnych, której celem jest zapoczątkowanie funkcjonowania danego klastra bądź rozwiązanie istotnych problemów już 
istniejącej, realnie działającej struktury klastrowej. W tym ujęciu inicjatywa klastrowa jest działaniem mającym na celu budowę sformalizowanej struktury, która ma wspierać inicjatywy kooperacyjne między poszczególnymi uczestnikami spontanicznie zainicjowanego klastra lub jego zalążka (Kowalski, 2010).

Z kolei autorzy publikacji pt. Tworzenie i zarządzanie inicjatywa klastrowa (Borowicz, Dzierżanowski, Rybacka, Szultka, 2009) wskazują, że jest to forma mobilizacji, integracji i komunikacji grupy podmiotów funkcjonujących w klastrze. Inicjatywa klastrowa nie może być więc być utożsamiana z klastrem, ponieważ z reguły nie uczestniczą w niej wszystkie funkcjonujące w klastrze podmioty. W rozumieniu A. Borowicz i współpracowników (2009) inicjatywa klastrowa służy przede wszystkim komunikacji - definiowaniu wspólnych celów i ukierunkowaniu konkretnych działań prorozwojowych (indywidualnych lub wspólnych), realizowanych później czy to przez poszczególne podmioty wchodzące w skład klastra, jego koordynatora, czy też przez konsorcja tych podmiotów. Badacze ci wskazują, że inicjatywę klastrową należy traktować przede wszystkim jako mniej lub bardziej sformalizowane forum spotkań, debaty i definiowania potrzeb klastra oraz kierunków jego rozwoju.

Podobne podejście prezentowane jest w The Cluster Initiative Greenbook (Sölvell, Lindqvist, Ketels, 2003). Inicjatywa klastrowa rozumiana jest tu jako zorganizowane działania zainteresowanych podmiotów (firm, administracji oraz środowiska naukowego), mające na celu przyspieszenie wzrostu i konkurencyjności klastra w regionie. Z kolei wspomniany już podręcznik pt. Tworzenie i zarządzanie inicjatywa klastrowa, przeznaczony dla władz regionalnych i przygotowany na zlecenie Urzędu Marszałkowskiego Województwa Wielkopolskiego (Borowicz i in., 2009), definiuje inicjatywę klastrową jako całą wiązkę działań podejmowanych na rzecz tworzenia i rozwoju klastra.

Abstrahując od złożoności pojęciowej problematyki klastrów, a tym samym prób badania tego rodzaju działalności przedsiębiorstw, w niniejszym opracowaniu zaprezentowano analizę wyników przeprowadzonego w 2013 roku przez GUS badania o innowacjach w przemyśle, którego dotyczyła także współpraca firm w zakresie inicjatywy klastrowej. GUS zdefiniował ją jako współpracę w ramach powiązań kooperacyjnych z różnymi instytucjami (także ze stowarzyszeniami handlowymi, jednostkami normalizacyjnymi, instytucjami finansowymi i naukowymi), zawiązanych w sposób formalny na podstawie listu intencyjnego, umowy stowarzyszeniowej, umowy o utworzeniu konsorcjum itp.

Jak wskazują wyniki badania, tak rozumiana współpraca w ramach inicjatyw klastrowych nie cieszyła się dużą popularnością wśród aktywnych innowacyjnie przedsiębiorstw przemysłowych w Polsce. W latach 2010-2012 współpracowało w ten sposób tylko nieco ponad 4\% z nich. Największy udział (8\%) firm współpracujących w inicjatywach klastrowych zauważa się w województwie śląskim. Natomiast najniższą aktywność w tym zakresie zaobserwowano w województwach małopolskim i lubuskim (mniej niż 2\% aktywnych innowacyjnie podmiotów).

W badanym okresie w województwach poziom zależności między udziałem przedsiębiorstw przemysłowych współpracujących z innymi podmiotami w ramach inicjatywy klastrowej a: 
a) udziałem współpracujących z innymi przedsiębiorstwami lub instytucjami w ogólnej liczbie aktywnych innowacyjnie przedsiębiorstw przemysłowych - nie był zbyt duży $(r=0,44)$,

b) udziałem przedsiębiorstw aktywnych innowacyjnie - był niemal żaden $(\mathrm{r}=0,02)$.

Biorąc pod uwagę rozkład udziału aktywnych innowacyjnie przedsiębiorstw współpracujących w ramach inicjatyw klastrowych w ogólnej liczbie firm aktywnych innowacyjnie według województw, podobnie jak w przypadku pozostałych analizowanych wskaźników, zauważa się, że wzrastał on wraz ze wzrostem wielkości przedsiębiorstw. Wśród małych firm zaangażowanie we współpracę $\mathrm{w}$ ramach inicjatyw klastrowych wykazały podmioty z zaledwie pięciu województw (śląskiego, dolnośląskiego, lubelskiego, łódzkiego oraz mazowieckiego), podczas gdy wśród przedsiębiorstw średnich było to już 14 województw (wszystkie oprócz opolskiego i lubuskiego).

Największy udział małych przedsiębiorstw współpracujących w ramach inicjatyw klastrowych w ogólnej liczbie przedsiębiorstw aktywnych innowacyjnie w tej grupie wielkości zanotowano $\mathrm{w}$ województwie śląskim. Wyniósł on ponad $8 \%$ i był o ok. 5 p.p. wyższy niż w województwach dolnośląskim, lubelskim i łódzkim oraz o 8 p.p. wyższy niż w województwie mazowieckim. Jednocześnie śląskie było jedynym województwem, w którym wartość omawianego wskaźnika dla małych podmiotów była wyższa niż średnia dla całego regionu.

Biorąc pod uwagę, że w latach 2010-2012 zaledwie 9,6\% małych przedsiębiorstw przemysłowych w Polsce wprowadziło innowacje, można sądzić, że brak wiedzy i świadomości tych podmiotów o korzyściach wynikających ze współpracy w ramach inicjatyw klastrowych (m.in. możliwość zwiększenia efektywności funkcjonowania, poprawy innowacyjności czy wejścia na większe rynki) przekłada się na niskie wskaźniki obrazujące poziom ich innowacyjności.

Jeżeli chodzi o przedsiębiorstwa średnie, to zasadniczo we wszystkich województwach udział przedsiębiorstw współpracujących w inicjatywach klastrowych w ogólnej liczbie aktywnych innowacyjnie podmiotów tej wielkości był wyższy niż w małych firmach. Wyjątek stanowiły średnie przedsiębiorstwa z województwa śląskiego - tutaj udział współpracujących w ramach inicjatyw klastrowych był o ok. 2,5 p.p. niższy niż notowany w grupie podmiotów małych. Najkorzystniej omawiany wskaźnik kształtował się wśród dużych firm - wyniósł on średnio $12,3 \%$ i wahał się od 5,6\% w województwie zachodniopomorskim do 27,3\% w województwie opolskim.

Przeprowadzona aglomeracja podobieństwa województw pod względem udziału przedsiębiorstw przemysłowych współpracujących w ramach inicjatywy klastrowej w ogólnej liczbie podmiotów wg wielkości pozwoliła wyłonić trzy skupienia. Pierwsze z nich (ryc. 3) cechowała przede wszystkim ponadprzeciętna aktywność małych firm. Udział podmiotów współpracujących w zakresie inicjatywy klastrowej w ogólnej liczbie firm był tu ponad dwukrotnie wyższy niż ogółem w przedsiębiorstwach przemysłowych. Z kolei wyróżnikiem skupienia drugiego była wzmożona aktywność dużych firm i znikoma małych podmiotów. Agregujące większość województw skupienie trzecie, oprócz tego, że również cechowała je niewielka aktywność małych firm dotycząca inicjatyw klastrowych, to także odznaczało się niższą niż średnio w Polsce współpracą wśród średnich i dużych zakładów przemysłowych. 
Ryc. 3. Skupienia województw podobnych pod względem udziału przedsiębiorstw przemysłowych współpracujących w ramach inicjatyw klastrowych w ogólnej liczbie przedsiębiorstw przemysłowych aktywnych innowacyjnie w latach 2010-2012

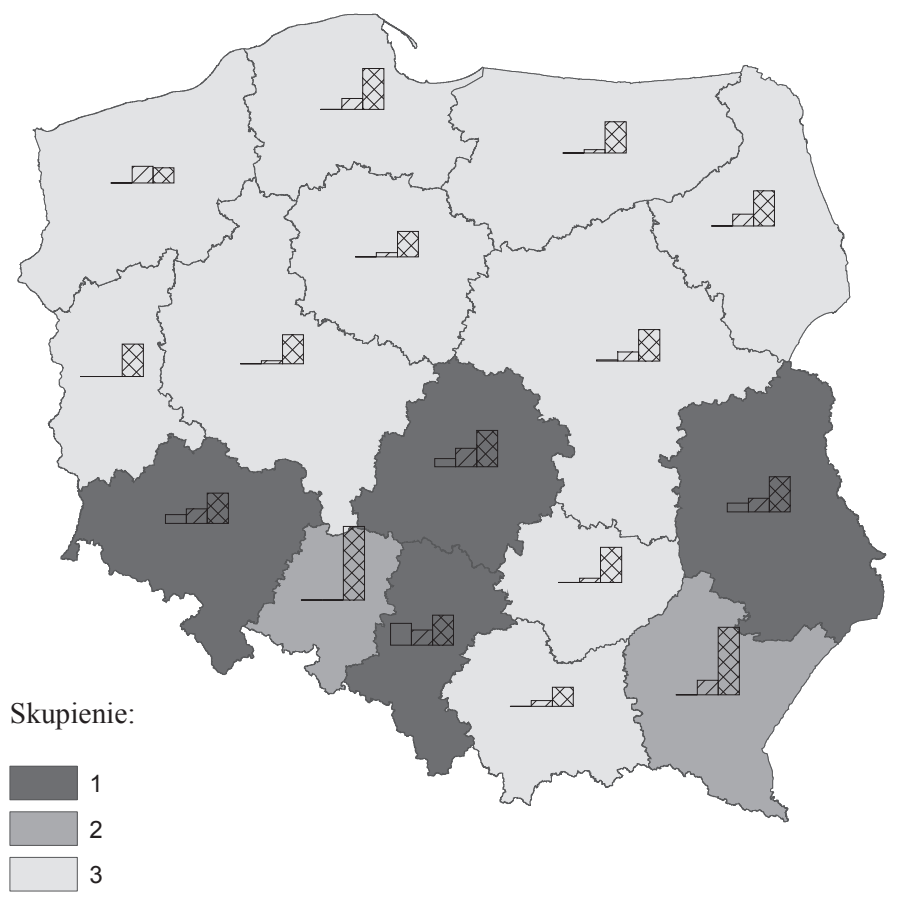

Udział aktywnych innowacyjnie przedsiębiorstw przemysłowych współpracujących w ramach inicjatyw klastrowych w ogólnej liczbie przedsiębiorstw przemysłowych aktywnych innowacyjnie wg wielkości (\%):

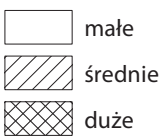

Źródło: opracowanie własne na podstawie danych GUS

Innym rodzajem badanej przez GUS kooperacji była współpraca przy innowacjach z innymi przedsiębiorstwami lub instytucjami w ramach innej niż klastrowa sformalizowanej formy współpracy. Zalicza się do niej m.in. wspólną aktywność podmiotów należących do izb i stowarzyszeń producenckich (w tym np. izb gospodarczych i handlowych), a także cechów rzemiosła czy przedsiębiorczości. Analiza otrzymanych wyników wskazuje, że tego rodzaju współpracy podejmowała się w Polsce niewielka, choć znacznie większa niż w przypadku inicjatyw klastrowych grupa przedsiębiorstw przemysłowych. Jedynie nieco ponad 7\% badanych wskazało, że w latach 2010-2012 uczestniczyli w takiej formie współpracy. Najaktywniejsze były firmy z województw opolskiego, mazowieckiego i świętokrzyskiego, gdzie udział aktywnych innowacyjnie przedsiębiorstw przemysłowych współpracujących 
w ramach innych niż klastrowe sformalizowanych form współpracy przekroczył 10\% (najwyższy był w województwie opolskim, gdzie wyniósł niemal 15\%).

Ryc. 4. Skupienia województw podobnych pod względem udziału przedsiębiorstw przemysłowych współpracujących w ramach innych niż klastrowe, sformalizowanych form współpracy w ogólnej liczbie przedsiębiorstw przemysłowych aktywnych innowacyjnie w latach 2010-2012

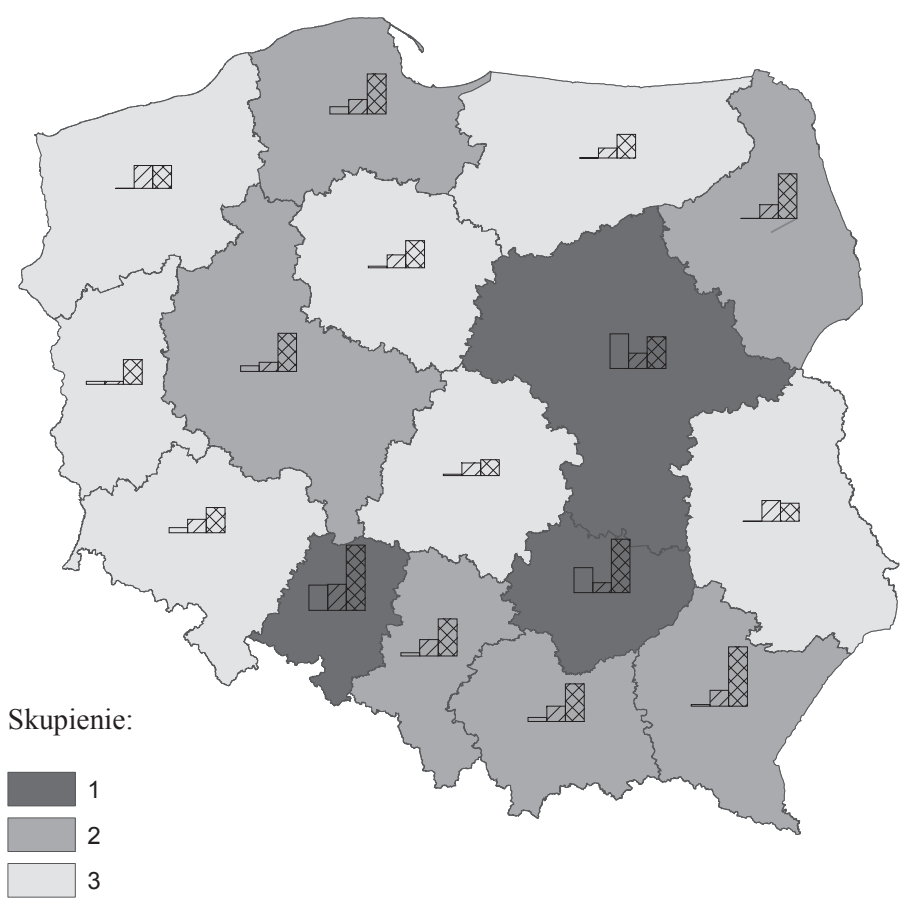

Udział aktywnych innowacyjnie przedsiębiorstw przemysłowych współpracujących w ramach innych niż klastrowe, sformalizowanych form współpracy w ogólnej liczbie przedsiębiorstw przemysłowych aktywnych innowacyjnie wg wielkości (\%):

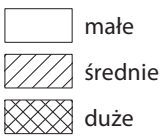

Źródło: opracowanie własne na podstawie danych GUS

Rozkład udziału firm współpracujących w izbach, stowarzyszeniach i innych formach nieklastrowych w województwach właściwie nie wykazywał zależności z rozkładem udziału firm współpracujących w ramach inicjatywy klastrowej $(r=0,09)$ czy z rozkładem udziału przedsiębiorstw aktywnych innowacyjnie $(\mathrm{r}=0,13)$. W pewnym stopniu był natomiast zbieżny z rozkładem udziału przedsiębiorstw współpracujących z innymi podmiotami $(r=0,47)$.

Podobnie jak we wcześniej analizowanych miarach współdziałania i innowacyjności odsetek współpracujących $\mathrm{w}$ takiej formie aktywnych innowacyjnie przedsiębiorstw 
przemysłowych w Polsce wzrastał wraz z wielkością podmiotów. O ile wśród małych firm wynosił niespełna 4\%, to w grupie dużych podmiotów było to już ok. 17\%. Wśród małych zakładów, które prowadziły takie formy współpracy, szczególną uwagę należy zwrócić na te działające w województwach mazowieckim, opolskim i świętokrzyskim. Ich udział w ogólnej liczbie przedsiębiorstw aktywnych innowacyjnie przekroczył w województwie mazowieckim 16\% (i był wyższy niż w pozostałych grupach wielkości przedsiębiorstw z tego terenu), natomiast w dwóch pozostałych województwach - 12\%. Takiej formy współpracy nie zanotowano w województwach lubelskim, podlaskim, warmińsko-mazurskim i zachodniopomorskim.

Jeśli chodzi o średnie przedsiębiorstwa, to udział tych, które współpracowały w ramach innych niż klastrowe sformalizowanych form współpracy, wahał się od ok. 13\% w województwie opolskim do nieco ponad 1\% w województwie lubuskim. Zaledwie w przypadku trzech województw udział ten przekroczył 10\% (we wspomnianym wyżej województwie opolskim oraz w województwach zachodniopomorskim - 11\% i lubelskim - nieco ponad 10\%).

Znacznie wyższe wartości miał omawiany wskaźnik wśród dużych przedsiębiorstw przemysłowych. W 14 województwach w Polsce udział dużych podmiotów w tego rodzaju współpracy przekroczył 10\%. Najwyższy wskaźnik zanotowano w województwie opolskim - ponad 31\%. Najniższe wartości wskaźnik ten osiągnął w województwach łódzkim (8\%) oraz lubelskim ( $9 \%$ i był niższy od zanotowanego dla działających w tym województwie przedsiębiorstw średnich).

Analiza aglomeracyjna tego wskaźnika wg wielkości przedsiębiorstw wykazała w województwach skupienia pierwszego najwyższą aktywność w tym zakresie - w każdej grupie wielkości zakładów przemysłowych wyższą niż średnio w Polsce, a w odniesieniu do małych firm - niemal czterokrotnie wyższą. W województwach, które znalazły się w skupieniu drugim, wyższe niż średnio w kraju było zaangażowanie w inne niż klastrowe formy współdziałania dużych przedsiębiorstw przemysłowych. Natomiast w skupieniu trzecim, poza zbliżonym do średniego w kraju poziomu zaangażowania w omawiany rodzaj współpracy firm średniej wielkości, w pozostałych grupach aktywność była znacznie niższa niż średnio w Polsce (zwłaszcza w przedsiębiorstwach małych).

\section{Podsumowanie}

Przeprowadzone analizy pozwalają stwierdzić, że zaangażowanie aktywnych innowacyjnie przedsiębiorstw przemysłowych w Polsce w latach 2010-2012 we współdziałanie z innymi podmiotami nie wykazuje zależności korelacyjnej z poziomem aktywności innowacyjnej. W tych latach w ogóle przedsiębiorstw przemysłowych w kraju współpracę z innymi przedsiębiorstwami lub instytucjami wykazała $1 / 3$ aktywnych innowacyjnie podmiotów. Poziom współpracy sformalizowanej, czy to w formie inicjatywy klastrowej, czy innej niż klastrowa sformalizowanej współpracy, był znacznie niższy, wręcz znikomy. W analizowanym okresie wykazało ją odpowiednio 4,4\% i 7,3\% aktywnych innowacyjnie przedsiębiorstw przemysłowych. Jednocześnie, tak w przypadku wskaźnika aktywności innowacyjnej, jak i udziału przedsiębiorstw przemysłowych w różnych formach współdziałania na polu innowacyjnym, 
zaobserwowano wzrost zaangażowania podmiotów wraz ze wzrostem ich wielkości. Zbadane przez GUS formy współdziałania w dużych przedsiębiorstwach przemysłowych były trzy lub czterokrotnie intensywniej wykorzystywane niż w przedsiębiorstwach małych.

Zdiagnozowana sytuacja potwierdza potrzebę inicjowania współpracy między przedsiębiorstwami a także z innymi podmiotami rynku w ogóle, w tym zwłaszcza wzmacniania postaw proinnowacyjnych opartych na współdziałaniu w sektorze MSP. Przebadane podobieństwo województw pod względem udziału przedsiębiorstw przemysłowych w różnych formach współdziałania, z uwzględnieniem wielkości firm, wykazało różny rozkład przestrzenny w zależności od przyjętej miary współdziałania. Oznacza to, że uwarunkowania rozwoju współpracy przedsiębiorstw aktywnych innowacyjnie powinny być dostosowane do wielkości podmiotów, ale też uwzględniać specyfikę regionalną. Synergiczne oddziaływanie przemyślanych i ukierunkowanych stymulant pobudzających działania innowacyjne i współpracę w tym zakresie powinno się przełożyć na podniesienie innowacyjności przemysłu w Polsce i polskiej gospodarki.

\section{Literatura \\ References}

Borowicz, A., Dzierżanowski, M., Rybacka, M., Szultka, S. (2009). Tworzenie i zarządzanie inicjatywa klastrowa. Podręcznik przygotowany na zlecenie Urzędu Marszałkowskiego Województwa Wielkopolskiego. Gdańsk: Instytut Badań nad Gospodarką Rynkową.

Burzyński, W., Kłosiewicz-Górecka, U., Kuczewska, L., Słonimska, B. (2008). Ekspertyza na temat: Wspótpraca podmiotów jako czynnik podnoszenia innowacyjności małych przedsiębiorstw w Polsce. Warszawa: Instytut Badań Rynku, Konsumpcji i Koniunktur.

Dominiak, P., Wasilczuk, J., Daszkiewicz, N. (red.) (2005). Małe i średnie przedsiębiorstwa w obliczu internacjonalizacji i integracji gospodarek europejskich. Gdańsk: Scientific Publishing Group.

Gorynia, M., Jankowska, B. (2008). Klastry a międzynarodowa konkurencyjność i internacjonalizacja przedsiębiorstwa. Warszawa: Wydawnictwo Difin.

Klastry. (2014, 16 listopada). Instytut Badań nad Gospodarką Rynkową. Pozyskano z http://www.klastry.pl/ mikstan/news.php

Klonowski, D. (2009). Innowacyjność sektora MSP w Polsce. Rządowe programy wsparcia a luka finansowa. Warszawa: Ernst \& Young Polska.

Kowalski, A.M. (2010). Kooperacja w ramach klastrów jako czynnik zwiększania innowacyjności i konkurencyjności regionów. Gospodarka Narodowa, 5-6, 1-17.

Larsen, P., Lewis, A. (2007). How Award-Winning SMEs Manage the Barriers to Innovation. Creativity and Innovation Management, 16(2).

Mazur-Wierzbicka, E. (2007). Wpływ zachowań proekologicznych na konkurencyjność przedsiębiorstw. W: T. Bernat (red.). Przedsiębiorstwo i państwo - wybrane problemy konkurencyjności. Szczecin: Wydawnictwo Print Group, 30-36.

Ortt, J.R., van der Duin, P.A. (2008). The evolution of innovation management towards contextual innovation. European Journal of Innovation Management, 11(4).

Porter, M.E. (2001). Porter o konkurencji. Warszawa: Polskie Wydawnictwo Ekonomiczne.

Ratajczak-Mrozek, M. (2013). Proces umiędzynarodowienia a współpraca przedsiębiorstw high-tech z podmiotami zagranicznymi. Gospodarka Narodowa, 1-2 (257-258), 53-70.

Rosińska, M. (2007). Globalna sieć biznesowa jako konsekwencja nowego paradygmatu konkurencyjności w gospodarce opartej na wiedzy. W: A. Jewtuchowicz (red.). Region w gospodarce opartej na wiedzy. Łódź: Wydawnictwo Uniwersytetu Łódzkiego, 69-81. 
Rozporządzenie Ministra Gospodarki z dnia 2 grudnia 2006 roku w sprawie udzielania przez Polską Agencję Rozwoju Przedsiębiorczości pomocy finansowej niezwiązanej z programami operacyjnymi (2014, 12 listopada). Dz.U. z 2006 r. nr 226, poz. 1651 z późn. zm. Pozyskano z https://bip. parp.gov.pl/files/164/165/373.pdf

Sölvell, Ö., Lindqvist, G., Ketels, Ch. (2003) (2014, 15 listopada). The Cluster Initiative Greenbook. Sztokholm. Pozyskano z http://www.hse.ru/data/2012/08/08/1256393499/GreenbookSep031.pdf

Stawasz, E. (2011). Polityka innowacyjna wobec MSP. W: P. Niedzielski, R. Stanisławski, E. Stawasz (red.), Polityka innowacyjna państwa wobec sektora matych i średnich przedsiębiorstw w Polsce - analiza uwarunkowań i ocena realizacji. Szczecin: Uniwersytet Szczeciński, 37-57.

The measurement of scientific and technological activities. Proposed guidelines for collecting and interpreting technological innovation data (1997). OECD, Eurostat.

Toborek-Mazur, J. (2004). Poprawa pozycji konkurencyjnej jako jedna z przesłanek połączeń przedsiębiorstw. W: Zarządzanie przedsiębiorstwem w warunkach integracji europejskiej, część II. Kraków: Wydawnictwo Akademii Górniczo-Hutniczej.

Tylżanowski, R. (2012). Wpływ innowacji na konkurencyjność polskich przedsiębiorstw. Studia i Prace Wydziatu Nauk Ekonomicznych i Zarzadzania, 25. Szczecin: Uniwersytet Szczeciński, 393-406.

Wolak, D., Żmijewska, A. (2014). Kierunki działań poprawiające efektywność wdrażania innowacji w firmach produkcyjnych sektora małych i średnich przedsiębiorstw w Polsce. Ekonomia i Zarządzanie. Kwartalnik Wydziatu Zarzadzania, 2(6). Białystok: Politechnika Białostocka, $57-70$.

Wiesława Gierańczyk, doktor, Urząd Statystyczny w Bydgoszczy, Kujawsko-Pomorski Ośrodek Badań Regionalnych, Referat Analiz i Badań Regionalnych. Doktor nauk o Ziemi, absolwentka geografii na Uniwersytecie Mikołaja Kopernika w Toruniu, wieloletni pracownik naukowy, obecnie kierownik Referatu Analiz i Badań Regionalnych w Kujawsko-Pomorskim Ośrodku Badań Regionalnych w Urzędzie Statystycznym w Bydgoszczy. Ukończyła studia podyplomowe z zarządzania finansami i marketingu, metod analizy i prezentacji danych statystycznych, menadżer projektu badawczo-rozwojowego. Autorka i współautorka oraz recenzentka kilkudziesięciu artykułów naukowych publikowanych w czasopismach krajowych i zagranicznych. Główne obszary jej zainteresowań badawczych to innowacyjność, geografia przemysłu, rozwój regionalny.

Wieslawa Gierańczyk, Ph.D., Statistical Office in Bydgoszcz, Kujawsko-Pomorskie Regional Survey Centre Regional Analysis and Survey Department. Ph.D. of Earth Sciences, graduate of geography on Faculty Nicolaus Copernicus University in Toruń, researcher, Head of Regional Survey Centre Regional Analysis and Survey Department in the Kujawsko-Pomorskie Regional Survey Centre of the Statistical Office in Bydgoszcz. She completed postgraduate studies of a field of: financial management and marketing, statistical methods for the analysis and presentation data, science research development manager. She is author or co-author of many reference works and reviewer of scientific papers published in national and international journals. Her main areas of interest are innovation, geography of industry, regional development.

Agata Sadoch, magister, Urząd Statystyczny w Bydgoszczy, Kujawsko-Pomorski Ośrodek Badań Regionalnych, Referat Analiz i Badań Regionalnych. Absolwentka historii Uniwersytetu Mikołaja Kopernika w Toruniu oraz studiów podyplomowych z zakresu metod analizy i prezentacji danych statystycznych Wyższej Szkoły Gospodarki w Bydgoszczy. Od kilku lat pracownik Referatu Analiz i Badań Regionalnych w Kujawsko-Pomorskim Ośrodku Badań Regionalnych w Urzędzie Statystycznym w Bydgoszczy. Współautorka tekstów poświęconych zagadnieniom rozwoju regionalnego, m.in. innowacyjności i konkurencyjności przedsiębiorstw, obszarów funkcjonalnych oraz dojazdów do pracy.

Agata Sadoch, Statistical Office in Bydgoszcz, Kujawsko-Pomorskie Regional Survey Centre, Regional Analysis and Survey Department. History graduate of Nicolaus Copernicus University in Torun 
and postgraduate studies statistical methods for the analysis and presentation data in the University of Economy in Bydgoszcz. For several years she is employee in Regional Survey Centre Regional Analysis and Survey Department in the Kujawsko-Pomorskie Regional Survey Centre of the Statistical Office in Bydgoszcz. Co-author of texts on issues of regional development in such areas as innovation and competitiveness of enterprises, functional areas and commuting.

\section{Adres/address:}

Urząd Statystyczny w Bydgoszczy

Kujawsko-Pomorski Ośrodek Badań Regionalnych

Referat Analiz i Badań Regionalnych

ul. Mickiewicza 10/16, 87-100 Toruń, Polska

e-mail: W.Gieranczyk@stat.gov.pl (Wiesława Gierańczyk)

e-mail: A.Sadoch@stat.gov.pl (Agata Sadoch) 